\title{
Pensamiento social sobre la infancia: una mirada sociohistórica desde el sur global ${ }^{1}$
}

\author{
Recibido: 17/08/2018 \\ Aprobado: 01/11/2018
}

\author{
ENRIQUE M. JARAMILLO GARCÍA \\ Universidad Mayor de San Marcos \\ ejaramillogarcia@hotmail.com
}

\begin{abstract}
RESUMEN
El presente trabajo pretende hilvanar algunas ideas para comprender y explicar la configuración de los discursos y representaciones en la historia del pensamiento social sobre la infancia, a partir de la colonización, y la imposición de un patrón del poder jerárquico y autoritario en la familia, particularmente la indígena, negra y mestiza, en el proceso de colonialidad del poder y el saber. Actualmente, en el imaginario social hay en disputa dos nudos culturales, cuando se trata de la infancia: la racionalidad relacional de las culturas originarias desde el sur global; y la racionalidad instrumental occidental, que se consolidó en el Perú con el pacto social de la modernidad en el siglo XIX, que perdura hasta nuestros días.
\end{abstract}

Palabras clave: Historia, pensamiento social, infancia, colonialidad del poder, imaginario social, modernidad.

\section{Social thought about infancy: A sociohistorical view from the Global South}

\begin{abstract}
The present work presents some ideas to understand and explain the configuration of discourses and social representations in the history of social thought about infancy, stemming from the violent and brutal occidental invasion, colonization, and the imposition of a pattern of hierarchical and authoritarian power in the infancy and family of indigenous and blacks, in the process of coloniality of power and knowledge. Notwithstanding that, there are two cultural knots in dispute with regards to infancy: the rationale of native cultures from the Global South, and the occidental rationale that was consolidated with the social pact of modernity in the $18^{\text {th }}$ Century, lasting until our days.
\end{abstract}

Keywords: History, social thought, infancy, indigenous, coloniality of power, social sciences, sociology, social pact, modernity.

1 Con algunas modificaciones, forma parte del capítulo II de la tesis: Sociología de la infancia y politicas sociales en el Perú: 2000-2010, presentada en la Universidad Nacional Mayor de San Marcos, para optar el grado académico de doctor en Ciencias Sociales, especialidad de Sociología. 


\section{Pensamiento social sobre la infancia: ¿herederos de Occidente?}

D esde una perspectiva sociológica, tenemos que comprender la historia del pensamiento social sobre la infancia como una explicación hermenéutica e interpretativa de la acción "social" (Weber, 2010), del comportamiento humano de los otros, de los vencedores, de aquellos seres humanos occidentales que llegaron a Abya Yala en los siglos XV y XVI, y que colonizaron, dominaron y explotaron a los vencidos, y cuyo comportamiento se basó en un proyecto de colectividad centrado en el olvido, la fragmentación étnica, el común empeño de imitar lo europeo y rechazar todo lo indígena y africano. Como dice Gonzalo Portocarrero (2015), la vida cotidiana de los vencidos se apoyaba en una sociedad disgregada y variopinta, atravesada por toda clase de jerarquías (étnico-raciales, económicas y de género), donde la precariedad de los vínculos sociales estaba marcada por la debilidad de los sentimientos comunitarios en una sociedad autoritaria y racista omnipresente.

En efecto, no podemos negar entonces que, en el sur global, somos herederos del pensamiento social occidental sobre la infancia que se inicia con la globalización de hierro, en 1492, y el proceso de expansión europeo, donde a las poblaciones conquistadas, colonizadas y explotadas ${ }^{2}$ se les impuso modelos de infancia, familia, creencias religiosas, expresiones artísticas y una sociedad basada en las jerarquías. España y Portugal, las potencias hegemónicas del siglo XVI, elaboran por primera vez el proyecto-mundo, expandiéndose por África, América y Asia, para terminar “occidentalizando" el mundo (Boff, 2006). De este modo, las poblaciones conquistadas fueron racializadas por el Estado colonial, en el proceso de la colonialidad del poder, ${ }^{3}$ que se prolongó

2 "De esa manera, las poblaciones colonizadas fueron sometidas a la más perversa experiencia de alienación histórica. Empero, la historia que es cruel con los vencidos suele ser también vengativa con los vencedores. Las consecuencias de esta colonización cultural no fueron solamente terribles para los 'indios' y para los 'negros'. Ellos fueron, es verdad, obligados a la imitación, a la simulación de lo ajeno y a la vergüenza de lo propio. Pero nadie pudo evitar que ellos pretendieran pronto a subvertir todo aquello que tenían que imitar, simular o vencer" (Quijano, 2009, p. 19).

3 "El nuevo sistema de dominación social tuvo como elemento fundacional la idea de raza. Esta es la primera categoría social de la modernidad. Puesto que previamente — no hay rastros eficientes de esta existencia - no tenía entonces, como tampoco tiene ahora, nada en común con la materialidad de universo conocido. Fue un producto mental y social específico de aquel proceso de destrucción de un mundo histórico y de establecimiento de un nuevo orden, de un nuevo patrón de poder, y emergió como un modo de naturalización de las nuevas relaciones de poder impuestas a los sobrevivientes de este mundo en destrucción: la idea de que los dominados son lo que son, no como víctimas de un conflicto de poder, sino en cuanto inferiores en su naturaleza material y, por eso, en su capacidad de producción históricocultural. Esa idea de raza fue tan profunda y continuamente impuesta en los siglos siguientes y sobre el conjunto de la especie que, para muchos, desafortunadamente demasiados, ha quedado asociada no solo a la materialidad de las relaciones sociales, sino a la materialidad de las personas. La vasta y plural historia 
durante los siglos XVI, XVII y XVIII, donde todo se hizo ejerciendo la violencia y un terror desmedidos sobre pueblos débiles. El Occidente europeo se reveló como la hiena de la especie humana, cuyas víctimas fueron los niños y niñas indígenas, negras y sus padres. Es así que nacimos ya globalizados, y por experiencia propia sabemos lo que es la modernidad/posmodernidad, sentida como un "globo de colonización" (Boff, 2006).

Durante este largo periodo de dominación colonial occidental, hubo expoliación y esclavismo en Asia, África, Europa, Oceanía, así como en América. En este escenario, los niños indígenas y negros fueron tratados como animales, seres inferiores y bárbaros, siendo sometidas a severísimos castigos y humillaciones. Como decía Roberto Mac-Lean y Estenós (1948), los niños negros eran trasladados de un lugar a otro, sin más consideraciones que las que pudieron tenerse con los becerros o los chivos. Los adultos, hombres o mujeres, eran obligados a caminar de veinticinco a cuarenta millas diarias como si fueran recuas de acémilas. En el momento de su venta en subastas públicas, se les examinaba los dientes - como se hace con los caballos-y otras partes del cuerpo para calcular la edad que tenían, determinar su estado de salud y apreciar su capacidad para un trabajo comparable al de las bestias. Los niños indios y los niños negros, desde los seis años, empezaban el trabajo esclavo en las plantaciones y otros espacios sociales de exclusivo dominio de los vencedores, el que solo terminaba con su muerte después de un lago vía crucis de sufrimiento (Mac-Lean y Estenós, 1948, pp. 26-27).

Este vía crucis se consolida después de la Primera y Segunda Guerra Mundial en el corto siglo XX (Hobsbawm, 1999), con la hegemonía de los Estados Unidos, que destruye las culturas regionales y no occidentales. Se hace hegemónico un único modelo de producción, el capitalista, asentado sobre la competitividad, destruyendo los lazos de solidaridad, socialidad y cooperación entre la infancia y las familias en el sur global. Y desde la década de 1980, surge la idea de que la humanidad está ingresando a una nueva época, donde la racionalidad neoliberal se impone de un extremo a otro del planeta, convirtiendo a la Madre Tierra en un inmenso banco de negocios, donde todo (metales, plantas, semillas, agua, genes, trabajo, educación, salud, etc.)

de identidades y memorias (sus nombres más famosos son de todos conocidos: mayas, aztecas, incas) del mundo conquistado fue deliberadamente destruida y sobre toda la población sobreviviente fue impuesta a una única identidad, racial, colonial y derogatoria: 'indios'. Así, además de la destrucción de su previo mundo histórico-cultural, a esos pueblos les fue impuesta la idea de raza y una identidad racial, como emblema de su nuevo lugar en el universo del poder. Y, peor, durante quinientos años les fue enseñado a mirarse con el ojo del dominador" (Quijano, 2008 pp. 101-102). 
es mercantilizado, se vende y se convierte en objeto de lucro (Boff, 2006). Estamos asistiendo a la deshumanización, ya que no sabemos valorar y reconocer a la infancia indígena, afrodescendiente y mestiza como seres humanos ${ }^{4}$ creativos que piensan, se resisten, se rebelan, se alzan y protestan contra toda forma de opresión, discriminación y humillación, y luchan por el derecho a la vida y a la libertad.

Desde la sociología reflexiva (Bourdieu y Wacquant, 2005) como herramienta de investigación, pretendemos comprender y explicar el significado de la génesis y matriz del pensamiento social occidental sobre la infancia, como resultado de un largo proceso de dominación, explotación y opresión. Por tanto, somos herederos de la epistemología occidental y eurocéntrica, y de la sociedad cristiana patriarcal, adultocéntrica, saturada de prejuicios coloniales autoritarios, donde los indios, los negros, mestizos, cholos y sus descendientes todavía siguen siendo considerados como una "raza abyecta" y "degenerada" muy difícil de redimir. ${ }^{5}$

\section{2. ¿Atrapados entre la modernidad y posmodernidad?: crisis y posibilidades de las ciencias sociales y la sociología}

El Perú republicano del siglo XXI transita aceleradamente por el camino de una sociedad que reconfigura notablemente sus fundamentos modernos. Asistimos a la reconfiguración de esa nueva sociedad, a la que se denomina posmoderna/modernidad líquida (Bauman, 2007), tecnotrónica, capitalista tardía, sociedad de control o panóptico (Foucault, 2012), sociedad del riesgo

4 "Emile Durkheim, uno de los padres de los fundadores de la sociología, habla de la singularidad del ser humano como ser social, capaz de crear utopía, de añadir algo a lo real. Esto es algo exclusivo de él, pues ningún animal es capaz de utopía. Por eso crea símbolos, proyecciones, sueños... Porque ve lo real transfigurado. Esta capacidad es lo que llamamos 'trascendencia', es decir, lo que trasciende, rompe, va más allá de lo ya dado... el ser humano es un proyecto infinito. Un proyecto que no encuentra en este mundo el marco adecuado para su realización [...]. El ser humano es un proyecto ilimitado, trascendente, y no es susceptible de ser encuadrado. Puede eso sí acoger amorosamente al otro dentro de sí; puede servirlo, superando cualesquiera límites. Pero es algo que hace únicamente en su libertad, y solo cuando se decide libremente a hacerlo, sin imposición alguna" (Boff, 2002, pp. 41-42).

5 "Y es que desde siempre la dominación colonial traicionó los principios que la legitimaban. El cristianismo fue distorsionado para cohonestar la servidumbre. El argumento fue que los indígenas tienden a la idolatría, por lo que solo en el vasallaje sus almas podrían salvarse. Y con la República, la acusación de apego a la idolatría se transformó en el cargo de ‘degeneración' de la raza. El indio, debido a las fiestas y borracheras, se había convertido en un ser 'abyecto', en la cristalización palpable de todo lo que debe ser rechazado. Situación que requería —igualmente - de una mano firme para redimirlos, gracias esta vez a la acción civilizatoria. El cristianismo — desde la invasión española - y la civilización en el siglo XIX sirvieron para justificar una explotación mayormente impía que, sin embargo, se quería pensar como orientada hacia el propio bien de sus víctimas" (Portocarrero, 2015, p. 325). 
(Beck, 2002), sociedad a la deriva (Castoriadis, 2006), sociedad de consumo (Baudrillard, 2009). Todas estas denominaciones nos confirman la sensación de que estamos en camino a un gran tránsito, a un cambio de época y bifurcación histórica, en medio de las incertidumbres del saber (Wallerstein, 2006, 2004). Este tránsito coloca como elemento distintivo del cambio a la revolución de las comunicaciones, en la sociedad del conocimiento e información. Junto con ello, se suman otros cambios significativos que van desde la colonialidad del poder (Quijano, 2005), el pensamiento de los límites, la diferencia colonial y la "matriz" poscolonial (Mignolo, 2007), el auge de la elección racional y la tribal social (Maffesoli, 2004). Otros autores señalan la envergadura de los cambios sociales, económicos, políticos y culturales en curso en un mundo desbocado por la globalización (Giddens, 2005; Bauman, 1999), ganado por el fundamentalismo neoliberal (Bourdieu, 2005; Boff, 2002), donde el choque de civilizaciones y la reconfiguración del orden mundial (Huntington, 2013) influyen en la vida y existencia social de las nuevas generaciones, a la que no son ajenas las infancias no solo indígenas, negras, mestizas, sino también de todos los sectores sociales, donde los estilos de vida de alto consumo, del confort material y el hedonismo ${ }^{6}$ están causando estragos irreversibles en sus vidas.

$\mathrm{Al}$ respecto, sobre los cambios que atraviesa nuestra sociedad, con mucho criterio Julio Mejía (2015, pp. 134-135) señala:

La sociedad actual es cada vez menos propicia para el contacto entre las personas, se ha transformado en un lugar de inseguridad y violencia cotidiana, el narcotráfico, el caos vehicular, las edificaciones permanentes, la suciedad, el desempleo, la informalidad, las pandillas juveniles y la criminalidad empujan a los habitantes a buscar ámbitos confiables, seguros, ordenados y 'libres' de la marginalidad social. Se privatiza el espacio de las ciudades, emergen urbanizaciones cerradas, condominios, balnearios, urbanizaciones residenciales exclusivas, clubs sociales privados, y el crecimiento de urbanizaciones residenciales semicerradas, que reproducen el cerco y enrejamiento parcial de calles, parques y plazas, lo que equivale a la parcelación, separación y exclusión social, con fronteras protegidas, con muros y vigilancia. De esta forma, la organización de la sociedad tiende a redefinirse en función del miedo frente a la delegación urbanística, la violencia y la corrupción.

6 "Se están creando nuevas generaciones de individuos sobre la base de paradigmas que los medios diseminan por todo el planeta, estilos de vida de alto consumo, de confort material, de hedonismo y de gran atractivo porque promueven la satisfacción inmediata de las necesidades materiales (el sexo, la droga, la moda, las diversiones), en la que se articulan el confort capitalista y la violencia de la barbarie neoliberal" (Silva Santiesteban, 2004, p. 12). 
El resultado es la privatización de la ciudadanía, el miedo de quedar desempleado, accidentado, atropellado, asaltado, violentado, preso, estafado, discriminado étnicamente en la ciudad, el temor cotidiano al otro en la calle se apodera de la vida social, la capacidad de organización, participación vecinal y una comunidad integrada se desvanece. El resultado es el surgimiento de un subciudadano carente de la dimensión pública, reducido únicamente al ámbito de las decisiones individuales y privadas.

A esta realidad, no son ajenas las infancias indígenas, afrodescendientes y mestizas, que son consideradas como seres peligrosos, desechables y/o descartables.

Ahora bien, Aníbal Quijano (2014: 18) denominaba a este nuevo periodo histórico "crisis raigal de la colonialidad global del poder", el que se manifiesta y expresa directamente en la reconfiguración de las relaciones del capital con el trabajo y en la crisis del calentamiento global que pone en riesgo no solo la propia vida del planeta, sino también la propia vida de las presentes y futuras generaciones. La especie Homo sapiens está siendo arrastrada hacia la máxima desigualdad social, bajo el control de grupos cada vez más reducidos. El sistema mundo moderno/posmoderno global incorpora la violencia abierta como elemento intrínseco de su reproducción, la violencia cínica se vuelve sistémica en las relaciones con la naturaleza y en las relaciones con los individuos, con las infancias y las familias.

En este tránsito de una sociedad moderna/posmoderna, en la que nos encontramos atrapados, cuando reescribimos la historia del pensamiento social sobre la infancia, Jaime Jhoseph (2005) nos ayuda a quitarnos la ceguera del conocimiento para hacernos ver que:

las ciencias sociales no pueden pretender capturar la verdad —el pecado original de la humanidad - , pero tampoco pueden limitarse a describir a la persona y sus relaciones con el otro, en la comunidad y en el ámbito societal. Aunque se quisiera postular un tipo de neutralidad de las ciencias, ello no es posible por la naturaleza misma de las relaciones humanas, que son su objeto de estudio. Estas relaciones no solo son cambiantes dentro de un mundo cerrado, sino que son parte de la creatividad misma de la sociedad y, por ello, las ciencias sociales requieren definir sus propios criterios de lo que es bueno y bello, de lo que se acerca a una verdad que siempre escapa a la dominación científica, pero que a la vez es esencial para las ciencias mismas.

En efecto, en medio de la crisis de carácter civilizatoria (Quijano, 2010; De Sousa, 2010a) en la que vivimos, el rol y las posibilidades de las ciencias sociales, de la sociología y los científicos sociales, es determinante para po- 
der (des)colonizar y deconstruir la razón ciega, neutral, indolente y perezosa (De Sousa, 2012) respecto de los hechos sociales, económicos, políticos y culturales en curso; y más aún, cuando se trata de la historia misma del pensamiento social sobre la infancia. Es en ese tránsito, como decía Pierre Bourdieu (2007), que la sociología, al igual que todas las ciencias sociales, tienen como misión descubrir los problemas ocultos de la sociedad; y al hacerlo tienen que ayudarnos a desentrañar las cosas ocultas y no visibilizadas, para dejar de minimizar la violencia simbólica que se ejerce.

Parafraseando a Jaime Joseph (2005), nuestro principal enfoque epistemológico se centra en la persona humana, es decir, en la infancia indígena, afrodescendiente y mestiza entendida no como un yo-pensador ontológicamente atomista, sino como un yo-otro, en la sociedad. Se trata de ir dando cuenta de los supuestos del cambio y cómo ellos van, a su vez, configurando las nuevas tendencias que, aunque todavía, no encuentran del todo su cauce y expresión manifiesta, si van expresando simbólica y cotidianamente sus nuevas modalidades expresivas para rechazar las prácticas sociales racistas, discriminadoras, autoritarias y antidemocráticas. Por ello nos planteamos las siguientes interrogantes: ¿Qué es lo que estos cambios pueden decir y cómo influyen en la vida social y afectiva de la infancia, en el tránsito de la modernidad/posmodernidad, y que muchas veces no somos capaces de percibir, por estar tan alejados de una sociedad donde la fragmentación del mundo social nos impide imaginar una comunidad cohesionada? ¿Cuáles deberían ser los nuevos roles que tendrían que cumplir las ciencias sociales, la sociología, así como los científicos sociales, en su acción social, investigativa y pedagógica a fin de ayudarnos a pisar tierra, y aprender a reconocer a la infancia indígena, afrodescendiente y mestiza como un proyecto infinito? ¿Qué posibilidades todavía tienen las ciencias sociales, la sociología reflexiva y crítica para desencadenar el debate, para así coadyuvar a la construcción de un nuevo proyecto histórico individual y colectivo (Castoriadis, 2005), en un país que vive en medio de una profunda crisis, ${ }^{7}$ donde la caída de las ideologías revoluciona-

7 “[...] según Castoriadis, la crisis de la sociedad contemporánea: es crisis de las significancias que sostienen la sociedad junta. Dicha crisis radica, por un lado, en la caída de las ideologías revolucionarias, pero, por otro, en la crisis de la misma ideología del progreso que no apuntaba solo a acumular riquezas, sino asumía que el progreso iba a proporcionar libertad, democracia, felicidad y una mejor moralidad. Que no se vaya creer que la obra de Castoriadis se reduce a esas dimensiones de crítica socioeconómica en donde, repetidas veces, se pregunta si no estamos en un 'callejón sin salida'. Es cierto que él no cesa de denunciar el fetichismo 'de cierto dominio racional' que caracteriza nuestros tiempos, pero al mismo tiempo está convencido de que solo se trata de un 'eclipse' de la otra gran significación imaginaria de la historia occidental, a saber, de la autonomía, especialmente la autonomía política. [...] una posible nueva 
rias, aparentemente, nos están llevando "hacia el abismo" (Morin, 2010) y a un "callejón sin salida"?

Responder a estas interrogantes, de manera sistemática, holística, enhebrada, de forma lógica y académica, es lo que se pretende dar en esta época de crisis civilizatoria y caída de las ideologías revolucionarias. Es en este escenario donde las ciencias sociales, y en especial la sociología, cobran aún mayor relevancia y trascendencia histórica, para ayudarnos a salir de este entrampamiento a la que nos han empujado la modernidad/posmodernidad.

\section{La racionalidad en las ciencias sociales: lo bueno, lo malo, lo bello, lo feo y lo verdadero, para analizar los hechos sociales en la vida y existencia social de la infancia}

¿Por qué es tan importante conocer la racionalidad en las ciencias sociales? Siguiendo a César Germaná (2002), la racionalidad en las ciencias sociales, nos ayudará a hacernos ver lo bueno, lo malo, lo bello, lo feo y lo verdadero en el análisis de los hechos sociales en la vida y existencia social de la infancia. Por ello, en la base de la reconstrucción de las ciencias sociales y la sociología se encuentra la necesaria descolonización de las disciplinas, de tal manera que se pueda plantear otras formas de conocer la vida y el mundo social ${ }^{8}$ de la infancia, e identificar que muchos de los problemas contemporáneos que aquejan a este sector de la sociedad tienen como raigambre colonial la violencia indirecta o estructural, así como la violencia simbólica que en nuestra historia ha tenido a la infancia y las familias pobres como sus principales protagonistas, donde la violencia física, o cualquier otra forma de coacción mecánica,

aurora después de estos tiempos sombríos, vemos dos conceptos arquitectónicos o dos dimensiones del ser humano: la imaginación creadora de la psiché humana y el imaginario instituyente social” (Guibal y Ibáñez, 2009, pp. 14-15).

8 "El racionalismo eurocéntrico, en el origen de nuestra disciplina, estableció fronteras prácticamente infranqueables en las diversas ciencias sociales que no le permitieron una adecuada comprensión del mundo social. La compartimentación del conocimiento ha limitado nuestro entendimiento de las complejidades de los sistemas sociales. Las nuevas perspectivas teóricas al abrir la sociología hacia las demás ciencias sociales han permitido dar cuenta de la complejidad del mundo social. Pero, además, posibilitan que la sociología no solo sea la búsqueda de la verdad, sino que esa verdad sea de un mundo deseable moralmente. Esto es, que desarrolle conocimientos comprometidos con la liberación del ser humano. Una sociología desvinculada de la lucha por alcanzar formas de sociedad emancipadas, como lo que quiere la aséptica perspectiva positivista, es incompatible con el auténtico quehacer sociológico. Finalmente, la descolonización del conocimiento sociológico no puede ser indiferente a las exigencias estéticas de un orden social nuevo. La búsqueda de una sociología que reúna lo verdadero, lo bueno y lo bello es una apuesta que nos permitirá salir del conocimiento instrumental del eurocentrismo" (Germaná, 2002, p. 15). 
han constituido los mecanismos principales de la reproducción social; y los medios más potentes para el mantenimiento de un orden social injusto, donde el núcleo de la violencia simbólica se encuentra en la "doble naturalización", que es consecuencia de la "inscripción de lo social en las cosas y en el cuerpo" (Bourdieu, 1970).

No podemos dejar de señalar que la fuente y el motor de la violencia indirecta o estructural y simbólica que se ejerce sobre los individuos, las familias y la infancia se realiza con su propia complicidad, al soportar estos las múltiples carencias en las que viven, en un país como el Perú, caracterizado por inusuales y abismales brechas marcadas por la desigualdad y pobreza (Banco Mundial, 2011), donde estas violencias se ejercen en un ordenamiento social inequitativo que ha alcanzado la sumisión inmediata, casi natural de los dominados y marginados, constituyendo el mecanismo principal de la reproducción social, el medio más potente para mantener el statu quo del orden social inequitativo, jerárquico, autoritario, adultocéntrico y excluyente (Germaná, 2002).

Quizá ello tenga que ver con la naturaleza de la modernidad/posmodernidad global, cuya matriz del "desarrollo" social, económico, político y cultural en el Perú ha contribuido a que la infancia y sus familias no hayan podido hilvanar y establecer los vínculos sociales y afectivos primarios que ayuden al desarrollo humano y a una mejor calidad de vida. Estos vínculos sociales y afectivos en la existencia social de la infancia, en el conjunto de las relaciones sociales, en las imágenes, las ideas, los signos y las normas que actúan en ellas, entre grupos o entre personas individuales, se han ido configurando en el proceso de la colonialidad del poder. ${ }^{9}$

En este proceso, la vida y existencia social de la infancia y la familia, en todas las formas en las que se producen, están asociadas con las relaciones sociales y con las relaciones subjetivas e intersubjetivas, pero muy debilitadas, diríamos casi fracturadas, por cuya razón no existe la cohesión social, identidad y sentido de pertenencia (CEPAL, 2007) entre la infancia y la institución familiar que se debate en una crisis profunda. La débil cohesión so-

9 "En el contexto de la colonialidad del poder, las poblaciones dominadas de todas las nuevas identidades fueron también sometidas a la hegemonía del eurocentrismo como manera de producir y de controlar las relaciones intersubjetivas, el imaginario, la memoria social y el conocimiento, sobre todo en la medida que algunos de sus sectores pudieron aprender la letra de los dominadores. Así, con el tiempo largo de la colonialidad, que aún no termina, esas poblaciones ('india' y 'negra') fueron atrapadas entre el patrón epistemológico aborigen y el patrón eurocéntrico que, además, se fue encausando como racionalidad instrumental o tecnocrática, en particular respecto de las relaciones sociales de poder y en las relaciones con el mundo en torno" (Quijano, 2009, p. 19). 
cial y el incremento de la violencia simbólica quizá sea uno de los factores de la carencia de una auténtica cultura afectiva, de respeto y escucha hacia la infancia, que está influida por los modelos familiares, sociales, económicos, políticos, culturales, laborales llegados e instituidos con los aluviones de Occidente (Mariátegui, 1980). En el ámbito de la cultura, es donde mejor se puede sacar a luz los mecanismos de la violencia simbólica, que se trasmite intergeneracionalmente, mediante el sistema de enseñanza, ya sea en la familia, en el espacio social de la escuela, la comunidad y la misma sociedad (Bourdieu, 2005).

Si bien es cierto que la violencia indirecta o estructural y la violencia simbólica han actuado y siguen actuando como instrumentos de dominación simbólica en la vida y existencia social de la infancia, en este proceso la sociología de las ausencias ha tenido un papel solo contemplativo y neutral, teniendo como objetivo mostrar solo lo que no-existe y, de hecho, lo no-existente como una alternativa no creíble a lo que existe, lógica derivada de la monocultura del saber ${ }^{10}$ y del aparente rigor del saber eurocéntrico (De Sousa, 2010b), que es resultado de la coerción de la colonialidad del poder, ${ }^{11}$ donde todavía habitamos y nos habitan. Actualmente, no obstante haber transcurrido más de cinco centurias de este hecho, continuamos sometidos a un horizonte de sentido histórico colonial moderno y eurocentrado, que nos impide entender y explicar este mundo y este tiempo, para ayudar a las víctimas del poder, la infancia y las familias humilladas y sometidas a la colonialidad del poder a subvertirlo y liberarse de esta situación (Quijano, 2009).

Por tanto, se hace necesario construir una auténtica representación de la historia del pensamiento social sobre de la infancia desde el sur global, acorde con su propia naturaleza y características, y con los saberes y cosmovisión de nuestras culturas originarias, que siempre han rechazado la violencia indirecta

10 “[...] es la monocultura del saber y del rigor: la idea de que el único saber riguroso es el saber científico y, por lo tanto, otros conocimientos no tienen la validez ni el rigor del conocimiento científico. Esta monocultura reduce de inmediato, contrae el presente, porque elimina mucha realidad que queda afuera de las concepciones científicas de la sociedad, porque hay prácticas sociales que están basadas en conocimientos populares, conocimientos indígenas, conocimientos campesinos, conocimientos urbanos, pero que no son evaluados como importantes o rigurosos. Y, como tal, todas las prácticas sociales que se organizan según este tipo de conocimientos no son creíbles, no existen, no son visibles. Esta monocultura del rigor se basa, desde la expansión europea, en una realidad: la de la ciencia occidental" (De Sousa, 2006b, p. 23).

11 "La colonialidad del poder (Quijano) es entendida como un modelo hegemónico global de poder instaurado desde la conquista que articula raza y trabajo, espacio y gentes, de acuerdo con las necesidades del capital y para el beneficio de los blancos europeos. La diferencia colonial y la colonialidad global (Mignolo) se refieren al conocimiento y dimensiones culturales del proceso de subalterización efectuado por la colonialidad del poder; la diferencia colonial resalta las diferencias culturales en las estructuras globales del poder existentes actualmente" (Escobar, 2010, pp. 77-78). 
o estructural y la violencia simbólica como instrumentos de dominación y subalternización, que les ha sido muy útil a los que ejercen el patrón del poder del Estado para imponernos una forma de vida, un pensamiento y una cultura ajena a la nuestra (Bourdieu, 1970: 19).

La sociología de las ausencias en la historia del pensamiento social sobre la infancia no solo está presente en la sociedad peruana y en América Latina, sino también, en mayor o menor grado, en Europa, América del Norte, Asia y África. Entonces, tomar distancia de la historia del pensamiento social occidental sobre la infancia no significa descartar o ignorar las posibilidades históricas de emancipación social de la modernidad occidental (De Sousa, 2010a). La otra forma de expresión de la sociología de las ausencias es el habernos naturalizado con la violencia indirecta o estructural, y la violencia simbólica, como instrumentos de dominación, y que una de sus manifestaciones más visibles es el maltrato generalizado a la infancia, cuyas consecuencias negativas se expresan en la falta de empatía y comprensión en la etapa en que el sujeto es más sensible a los diversos matices emocionales. Todavía se pretende enseñar a la infancia bajo las "reglas del adulto", en una sociedad adultocéntrica, racista, discriminadora, jerárquica y antidemocrática. ${ }^{12}$

Nuestro interés y enfoque epistemológico, cuando se trata de enhebrar las ideas de la historia del pensamiento social sobre la infancia desde el sur global, se centra en la persona humana como un ser de trascendencia histórica. Por tanto, la filosofía, las ciencias sociales y la sociología no pueden determinar absolutamente lo que es bueno o malo, pero sí pueden ayudarnos a reconocer una situación concreta como mala, por ejemplo, la desigualdad, violencia, pobreza, extrema pobreza en la que sobreviven miles de niños, niñas, adolescentes y sus familias. He aquí la importancia que cobra la racionalidad en las ciencias sociales.

\section{Un nuevo camino para las ciencias sociales y la sociología: la pertinencia de una sociología de las emergencias para recuperar la dignidad de la infancia}

En 1821 se produce la independencia del Perú, con el establecimiento del moderno Estado-nación (Quijano, 2013) que nace fracturado, por cuanto el

12 Hoy en día, en los primeros espacios de socialización de la infancia, la familia, la escuela y la sociedad no existen espacios de escucha, amor, afecto y ternura como formas de crianza. 
propio sistema independentista de inicios de la república no se realizó bajo un proceso de movilización integradora de los indios y negros, sino que fue obra de las élites criollas, ajenas a la cultura mayoritaria de la época. La cultura andina, con sus diversos matices, y la cultura africana fueron ignoradas por las élites políticas, y también por las ciencias sociales y la sociología (Castillo, 2015). Esta situación se prolongó durante el violento y corto siglo XX, donde los cambios, transformaciones y desarrollos de las sociedades modernas/ posmodernas produjeron nuevos hechos sociales, que a su vez la misma sociedad y sobre todo el Estado los convierten en problemas sociales que deben ser tratados y resueltos, o bien eliminándolos o bien logrando una recíproca adaptación entre tales problemas sociales y la misma sociedad. Por tanto, es indispensable la intervención de las ciencias sociales y la sociología para desbrozar nuevos caminos, para ayudar a convertirlos en problemas sociológicos, analizarlos y explicar las causas y razones que los produjeron e interpretar su sentido. La sociología como ciencia social tiene que ayudarnos a desvelar los hechos y problemas sociales que ocurrieron con la familia y con la infancia hace más de un siglo, y recientemente con la violencia política y el terrorismo en la época del miedo (Jaramillo, 2009).

El estudio sobre la situación social, económica, política y cultural de la infancia en pobreza, pobreza extrema, exclusión y la incidencia de las políticas sociales para su inclusión nos ayudará a entender y valorar mejor a las ciencias sociales y la sociología desde diversas perspectivas. Cuando hablamos de la historia del pensamiento social sobre la infancia, cualquier descripción de la sociedad hecha por sociólogos es ética; la idea de que la sociología está libre de valores es errónea (Bauman, 2009). No podemos ignorar que las ciencias sociales y la sociología tratan de agrupar a individuos preocupados sobre todo por lo que Giddens (1978) describió como "la política de la vida", donde las personas tienen que controlar por sus propios medios las relaciones sociales. En el caso del fenómeno social de la infancia, las ciencias sociales y la sociología tienen la posibilidad de servir a la causa de la libertad humana. Aquí cobra importancia la sociología de las emergencias que es lo contrario a la sociología de las ausencias, caracterizada por la razón indolente, neutra, ciega y perezosa (De Sousa, 2010a).

Ahora bien, desde la sociología de las emergencias estamos obligados a sustituir a la sociología de las ausencias (De Sousa, 2010a) para desvelar el vacío que existe entre el presente y futuro en que desarrollan su existencia social, la infancia y las familias, en medio de la desigualdad, pobreza, exclusión 
y violencia. La sociología de las emergencias, cuando indaga la historia del pensamiento social sobre la infancia en el sur global, debe ayudarnos a reconocer a toda la niñez, sin distinción de edad, raza, sexo, creencias religiosas, posición social y económica como sujetos de derechos. No olvidemos que el elemento subjetivo de la sociología de las emergencias es la construcción de conciencias anticipadoras, liberadoras, rebeldes y de inconformismo frente a la injusticia ${ }^{13}$ y postración en la que sobrevive la infancia, y ante la que no podemos mostrarnos como personas indolentes y neutrales. La sociología de las emergencias nos inculca y enseña a asumir una corriente cálida y esperanzadora, que es una corriente de la voluntad de acción, de transformación, de liberación, para vencer los obstáculos, e impide que no nos desilusionemos y perdamos fácilmente la esperanza. En suma, nos ayudará a abandonar esa idea de un futuro sin límites, y remplazarla por un futuro concreto, basado en esta emergencia: así vamos construyendo el presente y el futuro para la infancia y sus familias (De Sousa, 2006a).

La historia del pensamiento social sobre la infancia desde el sur global (crisis, guerras, genocidios, etc.) nos exige que tomemos partido políticamente en las controversias sociales. No tenemos que caer en la fácil tentación de desvincularnos de la lucha cotidiana por alcanzar formas de sociedad emancipadas y liberadas, a las que se opone y quiere someternos la aséptica perspectiva positivista, lo que es incompatible con el auténtico quehacer sociológico. La descolonización del conocimiento sociológico no puede ser de ninguna manera indiferente a las exigencias estéticas de un nuevo orden social (Germaná, 2002). Ahora bien, desde una epistemología de la sociología de las emergencias desde el sur global tenemos que aprender a conocer la diferenciación de las diversas esferas de valor que está en la base de la modernidad/posmodernidad occidental. Por tanto, el reencantamiento del mundo y de la historia del pensamiento social sobre la infancia tiene en la epistemología del sur global y la sociología de las emergencias sus herramientas más poderosas que iluminarán el camino oscuro y sombrío, para hacer que la infancia sea capaz de lograr una plena autonomía, por ser seres racionales, pensantes y rebeldes, con la disposición de ser independientes

13 “[...] vivimos en sociedades muy injustas en relación a las cuales no podemos ser neutrales. Debemos ser capaces de efectuar esta distinción, que es muy importante. [...]: tenemos unas teorías que nos dicen que no hay alternativa, cuando en realidad hay muchas alternativas. La gente sigue luchando por cosas nuevas, y ellos sí piensan que hay alternativas nuevas. [...] las ciencias sociales han dejado afuera: la distinción entre acción rebelde y acción conformista [...] cómo crear subjetividades rebeldes que en seguir discutiendo los conceptos de estructura y acción toda la vida" (De Sousa, 2006a, pp. 18-19). 
(Germaná, 2002). Solo así estaremos en la capacidad de ofrecer a la infancia y las familias ${ }^{14}$ un nuevo espacio social, donde reine una cultura de paz y justicia social (Mac Gregor, 2001).

Por ello, las ciencias sociales y la sociología de las emergencias del sur global tienen que constituirse en instrumentos válidos, tanto para los poderosos, así como para los pobres de la tierra (Martí), los condenados de la tierra (Fanon) y los condenados de la ciudad (Wacquant). Indudablemente, sus resultados se verán condicionados por las luchas sociales futuras que, en el siglo XXI, tienen que constituirse en un campo intelectual muy interesante y apasionante para la sociedad. Es conveniente, por tanto, que se entre a interactuar en este campo, armados con una combinación de humildad respecto de lo que sabemos, y con plena conciencia de que los valores sociales que esperamos prevalezcan. En consecuencia, el papel que les toca desempeñar a los científicos sociales como intelectuales orgánicos (Gramsci, 2004), especializados y comprometidos con el interés superior del niño, en la defensa y promoción de los derechos humanos de la infancia, es de trascendental importancia (Jaramillo, 2009).

\section{Dos nudos culturales en tensión respecto de la cosmovisión y racionalidad de la infancia: culturas originarias y cultura occidental}

La tensión y la crisis visible del viejo conflicto introducido por Occidente en el siglo XVI, ${ }^{15}$ a partir de la imposición de un proyecto de explotación sistemática, que sometió e impuso a las culturas originarias modelos de familia, infancia y sociedad, aún subyace. Pero si indagamos la historia del pensamiento social sobre la infancia en el sur global, esta todavía tiene su propia

14 Han transcurrido muchos años y, sin embargo, en el horizonte histórico del siglo XXI, la infancia y la familia, siguen afectadas por el incremento de la violencia social y política, la violencia familiar e intrafamiliar, la violencia urbana y rural, y la que surge entre ciudades contra las minorías, los niños y niñas, las mujeres, los ancianos, la violencia producida por el flagelo del terrorismo, la delincuencia criminal y la inseguridad, por las acciones marginales o por la amenaza de ellas, por las nuevas formas de acoso y pánico. Los principios y valores universales de la dignidad del ser humano no se observan en la vida cotidiana de la sociedad peruana, que está ganada por una cultura de la privatización fundada en el individualismo y en los intereses privados, una sociedad ganada por el consumismo exacerbado y el hedonismo.

15 " [...] a partir del siglo XVI, con la llegada de la civilización industrial y comercial, se diseña un proyecto de explotación sistemático de la naturaleza a partir de posiciones de poder. Cuanto más crece la dominación mediante la ciencia y la técnica, tanto más crece la destrucción masiva del medio ambiente. Los daños hoy son planetarios, afectando el suelo, el aire, las aguas, el clima, la flora, la fauna y la calidad global de la vida humana. Las veinticinco ciudades con ocho o doce millones de habitantes [como Lima Metropolitana] constituyen verdaderos purgatorios y hasta infiernos ecológicos" (Boff, 2000, pp. 34-35). 
racionalidad, a pesar de la hegemonía de la cultura occidental y eurocéntrica, que privilegia la edad cronológica del ser humano. En el imaginario social y las representaciones sociales de las culturas originarias, la infancia tiene otra connotación y racionalidad, gracias a la resistencia y la diversidad de las minorías étnicas que han hecho frente a la monocultura occidental. Se ha mantenido viva la cosmovisión ancestral de las culturas originarias, que considera a la infancia como parte importante de la vida social del ayllu y la comunidad.

Transcurridos más de cinco centurias de dominación occidental, las culturas originarias han resistido defendiendo sus usos y costumbres ancestrales, preservando con relativo éxito la idea de considerar a la infancia y la naturaleza como seres humanos animados e inanimados en la vida social del ayllu, incorporando e integrando en sus vidas, modelos, valores, conceptos, palabras, técnicas, animales y cultivos europeos, en todo el entramado social (Flores Galindo, 1988), preservando la ecología ambiental, la ecología mental, la ecología social y la ecología integral, frente a la lógica destructora y la deshumanización de la vida de la infancia impuesta por la cultura occidental (Boff, 2000).

Al respecto, María Emma Mannarelli (2002) nos recuerda que en el caso del modelo de desarrollo y la vida social de la infancia adquiere especial significado los referentes emocionales y formas de conducta, de acuerdo con las configuraciones de la estructura familiar que fuera introducida por Occidente. Sin embargo, en el caso de las culturas originarias no dejaron de reconocer a la infancia como wawas, y el concepto del sumak kawsay y/o buen vivir, que significa vivir con dignidad y en armonía con la ecología ambiental, social, mental, e integral, que nos enseña a tener una visión holística y liberadora de la sociedad (Boff, 2000).

Si esto es así, se nos presenta una magnífica oportunidad para formular la siguiente pregunta: ¿en qué medida varían en cada cultura los significados y representaciones sociales de la infancia? La respuesta es sencilla: hay en tensión y contraposición, dos nudos culturales, cuando hablamos del significado de la infancia. Estos dos nudos culturales se manifiestan cuando en el imaginario social y las representaciones sociales se yuxtaponen tres ideas: i) niño, objeto de protección tutelar; ii) niño, actor social, político y económico; y iii) niño, sujeto de derechos y protección integral. Estos conceptos son tan ambiguos y contradictorios, como la misma realidad que se pretende explicar.

Parafraseando a Antonio Gramsci, cuando hablamos de la infancia desde el sur global lo viejo se está muriendo y lo nuevo todavía no acaba de nacer. 
¿Pero qué es lo viejo y qué es lo nuevo? Lo viejo considera a la infancia como objeto de protección tutelar (doctrina de la situación irregular); lo nuevo, desde 1976, reconoce a la infancia como actor social, sujeto económico y político (Cussianovich, 2003), y desde el 20 de noviembre de 1989, con la Convención sobre los Derechos del Niño, todas las infancias en el mundo son reconocidas como sujetos de derechos y protección integral. En consecuencia, no podemos dejar de reconocer que la infancia, en cada cultura, ${ }^{16}$ en cada sociedad y en determinado momento histórico, es considerada como el presente y el futuro, a la que se le debe posibilitar el desarrollo de sus capacidades y la creatividad espiritual para una vida digna y de calidad (Plaza, 1998). Sin embargo, cuando se trata de la infancia en pobreza y pobreza extrema se le pretende condenar a la exclusión como seres desechables y peligrosos, a pesar del paradigma de protección integral. ${ }^{17}$

\section{La cosmovisión y racionalidad de la infancia en las culturas originarias}

Antes de la llegada de los europeos occidentales a Abya Yala, en el siglo XVI, estaban en pleno desarrollo las culturas originarias donde, en el ayllu, los niños y las familias, vivían bien en la comunidad. La infancia, más que un hecho biológico, constituía un asunto cultural. ${ }^{18}$ Esta forma de vivir bien, en armonía del hombre con la naturaleza, fue fracturada y trastocada con el afán expansivo que traían los conquistadores europeos, imponiendo el pro-

16 "En consecuencia cada cultura, cada sociedad, cada edad histórica tiende a elaborar un modelo de socialización/inculturación infantil, una serie de ideales de formación, un haz de normas y prescripciones que se refieren al niño y a su crecimiento. Todo esto a fin de hacer posible la realización de un individuo integralmente desarrollado en relación al modelo social deseado y considerado óptimo en aquel contexto sociocultural. En breve, podemos decir que cada cultura social/histórica tiende a elaborar su imagen de infancia (que es al mismo tiempo una descripción real y un modelo ideal de la infancia) y a hacerla girar como un principio normativo en el ámbito de la vida de la comunidad y, en particular, en la educación de las jóvenes generaciones" (Trisciuzzi y Cambi, 2003, p .12).

17 Los principios de la Convención sobre los Derechos del Niño son: i) derecho a no ser discriminado, ii) derecho a la supervivencia y el desarrollo, iii) derecho a la participación, y iv) el interés superior del niño.

18 "En la mayoría de estas sociedades se puede afirmar que la infancia, más que un hecho biológico, constituía un hecho cultural. Esto de alguna manera quiere significar la existencia de una auténtica cultura de la infancia en muchas sociedades prehispánicas. Una efectiva conciencia de la importancia de la reproducción y el crecimiento del grupo humano volcaba todo el interés y la expectativa sobre el éxito de los partos y el bienestar de los infantes. Múltiples ritos y ceremonias festejaban el embarazo y el nacimiento de los niños, pero además en algunas sociedades hubo finas consideraciones sobre la educación y preparación de los niños y las niñas para la vida adulta. Una especie de pedagogía social y moral instruía a los niños en los valores esenciales de la vida de esas comunidades. Esta elevada afectividad hacia los niños puede observarse en el lenguaje refinado, lleno de metáforas con las que los nombraban” (Rodríguez, 2007, p. 29). 
yecto hegemónico occidental ${ }^{19}$ de una sola cultura, oprimiendo y sometiendo a quienes consideraban inferiores (Boff, 2006; Flores Galindo, 1988).

A pesar de ello, las culturas originarias sobrevivieron, y hoy en día reviven y reflorecen, reivindicando el derecho que tienen a rescatar las relaciones económicas, sociales, políticas y culturales, que se sustenta y apoya en el ayllu de cada estancia, de cada pueblo, de cada familia, de cada comunidad. Las culturas originarias siguen luchando contra todos los prejuicios raciales que reposan pesadamente en nuestras vidas e identidades como una diferencia insalvable y natural. Sin embargo, desde las mismas raíces sociohistóricas y culturales de las poblaciones originarias emerge un nuevo horizonte de sentido histórico, que les da fuerzas para seguir luchando y persistiendo para vivir bien (allin kausakuy), en un mundo vivo y recíproco. ${ }^{20}$

En la racionalidad de las culturas originarias, todos los seres vivos e inanimados tienen vida y son parte de la vida social de la comunidad, por consiguiente, la infancia es un sujeto social, activo y protagónico, por ser parte consustancial del ayllu, la familia y la comunidad. Todos y todas son considerados personas: los humanos, la naturaleza, la tierra (Pacha Mama) y las deidades; todos son niños, también lo son los cerros (apus), las semillas, los ríos, los bosques, y como tal tienen derecho a ser respetados. Las relaciones subjetivas e intersubjetivas están sustentadas en la conversación, en el entendimiento, en la crianza mutua, en las muestras de solidaridad, reciprocidad y

19 " [...] constatar la existencia de un saldo enormemente negativo de Occidente con respecto a los muchos 'otros'. La cultura de la identidad occidental siempre ha experimentado grandes dificultades para implicarse con el otro de un modo benévolo. La estrategia consistía, más o menos, en lo siguiente: o se incorporaba al otro de manera subalterna, negándole así su identidad, o lo esclavizaba, o lo excluía considerándolo al margen, o simplemente lo destruía" (Boff, 2006, p. 119).

20 "En un mundo vivo y de recíprocos, la tranquilidad de cada integrante depende de la tranquilidad de los demás, ya sea desde la pareja, la familia, el ayllu y la comunidad. Por otra parte, al papel central que juega la pareja como unidad celular de una comunidad andina en la representación de la vida, corresponde señalar aquellas formas y maneras con las que las personas mayores y autoridades acompañan en cada momento de la vida, y son: es casi imposible formar una pareja al margen del ayllu y de las otras formas de vida debido al valor que se le asigna al hecho de tener un amparo. Una pareja formada por decisión personal, como ocurre en la sociedad moderna, dura mientras mantiene unidad y respetan sus intereses. Si se daña la unión, se daña toda la comunidad, es decir, la unidad sin la comunidad es insostenible. La conformación de la pareja está estrechamente ligado a la práctica de criar y sustentar a la comunidad. A través de ellos (warmiqari), la comunidad humana asume íntimamente el deber de contribuir a la regeneración de la vida. No se puede comprender a la pareja como relación de dos personas (mujer y varón) unidos por responsabilidades y tareas, como ocurre en el mundo moderno, sino como expresión de la comunidad. El enamoramiento compromete a la comunidad y a las deidades, que se expresa en una serie de eventos colectivos, promovido y vigilado por la familia y el ayllu hasta concretarse en matrimonio. Tampoco la vigilancia termina con el matrimonio, en caso de dificultades, se cuenta con la orientación y el acompañamiento de sus padres y del ayllu, además de existir una serie de autoridades carismáticas cuya función vital es la crianza de la familia. Son opuestos a la vivencia comunera las decisiones unilaterales y toda actitud individualista" (Asociación Bartolomé Aripaylla, 2014, p. 62). 
relacionalidad colectiva donde conviven respetuosa y amorosamente el hombre y la naturaleza (Jaramillo, 2004).

En la vida y existencia social de las culturas originarias, la noción de edad cronológica de la infancia no es tan importante. La edad cronológica, en una sociedad de concepción histórica circular, sigue siendo inexistente (Portocarrero, 1995). Por tanto, no emplean los conocimientos para definir la edad de los individuos, ni mucho menos para contar los años al modo del Viejo Mundo. Más bien se rigen por otros conceptos y enfocan los sucesos de manera distinta, de forma holística. John Rowe, al investigar las edades en los centros incaicos, se percató de que los incas no contaban sus edades, las personas se clasificaban no por la edad cronológica, sino por las condiciones físicas y su capacidad en el trabajo (Rowstorowski, 1988).

Actualmente, en las comunidades originarias andinas y amazónicas, todavía encontramos diferentes denominaciones, cuando se trata de la infancia: wawa, waway, wawakay. De hecho, está muy claro que la noción de wawa suele referirse no solo a las wawas humanas, sino también a los frutos de las wawas como producto de la tierra, de la Pacha Mama. En este sentido no se puede pensar de ninguna manera al ser humano desvinculado de su hábitat cotidiano y natural. En esta visión ecológica, todo lo que existe coexiste, y todo lo que coexiste preexiste y subsiste a través de una tela infinita de relaciones inclusivas. Todo se encuentra relacionado, fuera de esta relación no existe nada. Al reafirmar la interdependencia de todos los seres animados e inanimados, la ecología funcionaliza todas las jerarquías y niega el "derecho" de los más fuertes. Todos los seres cuentan y poseen su relativa autonomía, nada es superfluo o marginal. Cada ser compone un eslabón de la inmensa corriente cósmica que da la fe y esperanza de un mundo nuevo para el buen vivir. La ecología exige una visión de totalidad, esta no es resultado de la suma de las partes, sino de la interdependencia orgánica de todo con todo, del grande y el pequeño. ${ }^{21}$

21 " $[\ldots]$ no podemos pensar al ser humano desvinculado de la tierra. [...] La tierra es mucho más que una fuente de recursos, siempre limitados y algunos de ellos no renovables. La tierra es un superorganismo vivo, un 'otro', con su diferencia irreductible, y es al mismo tiempo otro próximo, porque somos parte integrante de él. Reconocer su alteridad nos permite construir la proximidad y unas relaciones de convivencia benevolente. Tanto los acuerdos políticos entre los pueblos como los pactos sociales deben fundarse en el pacto natural. Sin la garantía de permanencia y continuidad de la naturaleza y de la Tierra, todos los demás acuerdos carecen de base y son imposibles. Se trata de una situación nueva para la humanidad. Antaño, podía suponerse que la Tierra había existido siempre y constituía el sustento garantizado de cualquier proyecto humano. Hoy sabemos que no es así, pues el futuro de la Tierra no está garantizado en absoluto, dada la capacidad destructiva de la especie humana, sapiens et demens" (Boff, 2000, p. 119). 
Desde esta manera, desde la perspectiva ecológica natural, social y mental, las representaciones sociales de la infancia se van construyendo desde una actitud afectiva basada en el respeto, cariño, amor, amistad, escucha, tolerancia, afecto y ternura. Este simbolismo lingüístico tiene que ver con la concepción y el significado que adquiere la wawa en las comunidades. Por ejemplo, cuando los adultos se refieren a las wawas, les atribuyen un valor simbólico y real sumamente positivo. Las wawas significan para ellos fuerza, esperanza, refugio, respeto mutuo, reciprocidad y solidaridad, algo sumamente valioso, que ayuda al adulto. La infancia, tiene un significado muy profundo, que se ratifica como positiva cuando la crianza es comprendida como un tiempo para pasar la vida todos juntos - es decir, adultos y wawas - y en este proceso la wawa es considerada, desde el momento mismo que se encuentra en el vientre materno, como un miembro activo de la comunidad, y constituye un elemento que le da vida a la familia y, por la ternura que transmite, es el ser privilegiado para comunicarse con los dioses, con los apus. Las wawas tienen un papel fundamental en los ritos religiosos, porque encarnan la energía, la habilidad para jugar y atraer la mirada de los dioses de los Andes por su inmensa belleza. La wawa es un momento, una dimensión de la vida que se integra a la comunidad y se realiza a través de dos formas: la primera, mediante el juego, y la segunda, en las actividades cotidianas que realiza para ayudar en el ámbito de la vida familiar con acciones basadas en la solidaridad y reciprocidad. La wawa adquiere sistemáticamente saberes sobre las labores domésticas, el conocimiento de las plantas medicinales, el mundo animal y el significado de los fenómenos naturales, de la rica biodiversidad que la naturaleza les ofrece, en el encuentro que deben sostener con la naturaleza, con la tierra, como parte del equilibrio ecológico social que les permita el buen vivir (Escobar, 2010).

En lo lúdico, el aprendizaje se produce basado en los sentidos y la sensualidad, la expresividad de los afectos, la amorosidad, de los vínculos, la reciprocidad, de forma espontánea construyendo un "yo comunitario", un "yo social" que descansa sobre un "nosotros". Toma importancia vital la otredad comunitaria en el equilibrio de la vida (Ayllón, 2002). En la cosmovisión de las culturas originarias, existe un profundo respeto de los saberes acumulados por las wawas, saberes socialmente construidos en la práctica comunitaria (Freire, 1998), que cotidianamente son vivenciados buscando siempre el allin 
kawsay $^{22}$ (vivir bien), en la vida social cotidiana del ayllu, la familia y la comunidad.

\section{La cosmovisión y racionalidad de la infancia en la cultura occidental}

Detrás de la palabra cultura, en la cosmovisión y racionalidad occidental se esconden muchos enigmas respecto de la infancia y la familia. En su imaginario social, la infancia está estrecha e íntimamente relacionada con la edad cronológica y biológica; y también con la familia, que tiene como fin esencial el proteger y garantizar el funcionamiento de los mecanismos sociales fundamentales que se refieren a la producción y reproducción de la vida inmediata. La infancia en esta óptica es una unidad subalterna (Trisciuzzi y Combi, 2003). Esto significa que el sujeto se clasifica de acuerdo con el tiempo biológico, según las etapas de su estado y desarrollo físico. La infancia como objeto de protección tutelar todavía tiene un alcance regional y global, no obstante, la vigencia de la Convención sobre los Derechos del Niño revela inmensas brechas entre lo expresado y deseado. ${ }^{23}$

La infancia en la cosmovisión y racionalidad occidental siempre fue considerada como "menor", "incapaz", "en desarrollo" y, por tanto, tenía que allanarse permanentemente al "cuidado" y "protección" de sus padres o de la sociedad adulta. En caso de alguna trasgresión a las normas de la sociedad, debía ser sometida a un orden jerárquico, tutelar y autoritario (Nugent, 2010). En este sentido, como afirma José Sánchez-Parga (2014), se trata de prácticas y discursos infantilistas tendientes a reforzar el infantilismo de los niños (lo transitorio), en detrimento de sus condiciones personales (lo duradero). Esto desconoce que la persona del niño es la misma antes incluso de que el niño

22 "La existencia de varias culturas implica diferentes maneras de comprender el mundo, conocer y vivenciar, formas de solucionar y enfrentar los problemas. [...]. La visión moderna del mundo es una más, no la única como pretende. En la cosmovisión de las familias de los distritos de Chuschi, Vinchos y Totos, [...] allin kawsay (vivir bien) reposa en dos aspectos centrales: una vida digna y en suficiencia (mana pisikuy), y una vida colectiva y armoniosa (huklla hawkalla kausakuy), que en conjunto conducen a un sumak kawsay (vivir promisoriamente). Ninguno de estos se equipara con la noción moderna de bienestar, pero cada vez más se requiere equiparar y suplantar con aquello que se enseña en la escuela y se difunde a través de los medios de comunicación: la 'buena vida' de ciudad, como la verdadera vida humana definida desde el bienestar material" (Asociación Bartolomé Aripaylla, 2014, p. 56).

23 " "...] la Convención sobre los Derechos del Niño como producto cultural de origen occidental, elaborado fundamentalmente a partir de las concepciones dominantes sobre la infancia emanadas de los países industrializados de Europa y América del Norte. En este sentido, la Convención representa el hito más importante del proceso de globalización del ideal occidental referido a la posición del niño en la sociedad contemporánea" (Pilotti, 2001, p. 13). 
nazca, atraviesa todas las edades de la infancia, y es también la misma persona que deviene adulto. Estas prácticas y discursos occidentales son reforzados por el enfoque jurídico-tecnocrático; la persona del niño solo parece interesar en su condición infantil, pero al día siguiente de cumplir dieciocho años, esa persona deja de interesar. Entonces, ¿cómo explicar y justificar que el niño de un día para otro se queda sin derechos? (Sánchez-Parga, 2004).

Al respecto, hay un hecho que merece ser revelado: desde la fase primitiva hasta la burguesa, y más allá, son siempre los adultos aquellos que hablan de la infancia, la describen y la interpretan, y elaboran las diversas imágenes de la niñez como una entidad sin voz. De este modo permanece una distancia constante y perdurable entre el niño (real de carne y hueso) y las imágenes de la infancia que las culturas elaboran. La teoría no refleja la realidad del niño, sino que la deforma, ignorando zonas oscuras, problemas y diferencias. Se revela de este modo la ideología occidental de la infancia (Trisciuzzi y Combi, 2003).

Por otra parte, cabe precisar que en la cosmovisión y racionalidad occidental, en el aspecto racial y religioso del Perú colonial, la niñez mestiza, las castas indias y africanas sufrían un doble prejuicio a los ojos de las élites europea y criolla. De un lado, se asumía que los niños que habían sido concebidos fuera del matrimonio llevaban consigo el oprobio de la ilegitimidad; y de otro, las mujeres madres de estos niños ilegítimos eran calificadas como madres vergonzantes. La concepción materna fuera del matrimonio era considerada un pecado carnal por la Iglesia católica. La ilegitimidad de los niños, en la Lima del siglo XVII, era elevada en todos los grupos: más del $40 \%$ entre los blancos y mestizos, y $70 \%$ entre los negros y mulatos. Los mestizos también eran discriminados porque les faltaba la llamada pureza de sangre, y las sospechas de idolatría de su pasado perduraban. ${ }^{24} \mathrm{El}$ racismo persistente profundamente arraigado en el mundo hispano, y muchos de estos prejuicios

24 Gonzalo Portocarrero (2015) pone como un ejemplo vivo y símbolo del desprecio y discriminación de la que eran víctimas los niños indios y afrodescendientes a Francisco Fierro (Pancho Fierro), nacido en 1807, hijo de Nicolás Fierro, quien fue doctor, presbítero y cura de la doctrina de San Damián, perteneciente a una familia importante de la Lima criolla de la época, y María Carmen Palas, su madre, quien fue una esclava negra y criada. Al poco tiempo de nacer Francisco, su madre fue vendida como esclava a una familia vecina. De esta manera aparentemente se trataba de evitar el escándalo que significaba para la época la relación sentimental entre el joven estudiante de teología y una negra esclava, casi una niña. Pancho Fierro vive entre dos mundos. No era totalmente rechazado por la familia de su padre, quien poco tiempo después vuelve a comprar a la madre. Su tía paterna deja al niño Pancho Fierro como herencia una parte de su casa. Y, sobre todo, no nace esclavo por expresa disposición de su familia paterna. En consecuencia, no es un esclavo más, pero tampoco es que haya sido aceptado como un igual. Una demostración de ello es que su padre no firma su partida de bautismo. En realidad, como muchos en la sociedad limeña colonial, vive en la penumbra de la ilegitimidad. Es probable que Pancho Fierro en su infancia se haya desempeñado 
estaban codificados por la ley española. Por ejemplo, la prueba de pureza de sangre era exigida a los candidatos a cargos públicos y a quienes postulaban a la universidad y, a su vez, era un requisito indispensable para ejercer profesiones como el derecho (Klarén, 2004).

Desde esta perspectiva, durante los siglos XIX y XX, en el Perú republicano y en América Latina la mayoría de los intelectuales tenían la certeza de que la infancia indígena, afrodescendiente y mestiza eran de razas inferiores que bloqueaban el camino del progreso y el desarrollo (Galeano, 2001). Este pensamiento colonial y eurocéntrico aún sigue vigente, en un país y sociedad donde la colonialidad del poder aún habita en nuestras subjetividades y mentalidades, la que debe ser (des)colonizada y/o deconstruida por medio de las ciencias sociales y la sociología reflexiva en favor de las infancias que viven en una realidad socioeconómica y cultural en la que se manifiestan las injusticias sociales (Pilotti, 2001).

\section{La infancia en el pacto social de la modernidad}

El pacto social de la modernidad, se instituyó en Europa en el siglo XVIII ${ }^{25}$ con el triunfo de la Revolución francesa, ofreciendo a la humanidad la trinitaria: libertad, igualdad y fraternidad. En el caso del Perú y América Latina, tanto la infancia indígena, africana, mestiza, y sus padres no fueron considerados como sus beneficiarios. El pacto social de la modernidad se consiguió gracias a la concentración de medios de actuación en manos de cierta élite que se definía a sí misma como racional, y que afirmó su papel dirigente en contra del resto de fuerzas supuestamente irracionales. Una vez alcanzada el poder, permitió a Occidente tener la supremacía durante siglos, aunque al precio de la escisión y polarización de la sociedad en todos los aspectos.

En el Perú, el poder desmedido que se ejerció desde la instauración del pacto social de la modernidad se extiende durante los siglos XIX, XX y los

como empleado doméstico, entre consentido y puesto en su sitio por el color de su piel y su posición en la jerarquía social de la época.

25 “Cuando la 'modernidad europea' se afirma en el siglo XVIII, con las ideas de igualdad social, de solidaridad social y de ciudadanía, la idea de raza estaba ya activa y actuante. Había sido producida desde fines del siglo XV en plena conquista ibérica y destrucción del mundo histórico previo; ya estaba activa en el nuevo universo del capital, la industrialización, de los conflictos sociales como una radical y profunda idea de desigualdad entre la población de nuestra especie. Es decir, las ideas de 'raza' y de 'igualdad social' comienzan, en la modernidad europea y eurocéntrica, a operar, paradójicamente, no solo al mismo tiempo, sino en el mismo movimiento de la historia" (Quijano, 2013, p. 23). 
albores del siglo XXI, en un contexto mundial que bañó con su ideología todo el planeta, y de cuya concepción económica, social, política y cultural se nutren actualmente nuestras sociedades. Cuando se trata de la niñez, seguimos siendo tributarios de las ideas y la cultura de una infancia instituidas por la modernidad occidental. Transcurridas casi dos centurias de este pacto social, la vida de la infancia en pobreza y pobreza extrema todavía se mantiene en manos de las decisiones políticas de ciertas élites privilegiadas que ejercen el patrón del poder del Estado y hasta la fecha no han sido capaces de hacer realidad sus promesas.

Ahora, si bien es cierto que el pacto social de la modernidad se establece en el Perú, con el moderno Estado-nación en 1821, en los hechos no nacimos como una nación republicana. En el siglo XIX, fuimos una sociedad llena de resabios coloniales heredados, donde la jerarquización y el racismo fueron mucho más importantes que la igualdad entre todos los peruanos. En la nación no hubo un mutuo conocimiento entre sus integrantes, por tanto, fue una sociedad discriminadora (Portocarrero, 2015).

En este mismo sentido, Enrique Jaramillo (2009) parafraseando a Cotler (1994) sostiene:

En el Perú desde su constitución como Estado-nación republicano, después de la proclamación de la independencia en 1821, se han turnado en el poder, caudillos civiles y militares con una concepción patrimonialista y de clientelismo político, que en las diferentes etapas del devenir histórico del país no supieron solucionar los acuciantes problemas económicos, sociales políticos y culturales de grandes sectores de la sociedad peruana integrada en su mayoría por las clases populares. Por ejemplo, durante los gobiernos de la oligarquía, el Perú fue una república sin ciudadanos (López,1997), porque las grandes masas indígenas y negras fueron tratadas como mano de obra barata de producción de riqueza para las clases dominantes, y en ningún momento tuvieron el reconocimiento de ciudadanos.

En este contexto, la infancia era considerada como objeto de protección tutelar por su peligrosidad.

La prolongada dominación oligárquica estuvo sustentada en la explotación estamental de terratenientes y capitalistas, que se hacían llamar blancos, sobre una e indiferenciada masa de campesinos indígenas y de reducidas capas populares y medias urbanas, compuestas por criollos, mestizos y negros. Esta forma de explotación de características étnico-social, que supo combinar magistralmente la plusvalía con variadas formas no capitalistas, tuvo su correlato en la sistemática exclusión de los intereses populares de usufructuar 
los recursos del Estado. Esta fragmentación estamental de la sociedad peruana fue la causante del establecimiento de relaciones económicas y sociales de patrón-cliente, y la cultura señorial que se estableció eran algunos de los factores que dividían abismalmente a los sectores dominados de los dominantes.

Si bien es cierto que es en la Inglaterra en el siglo XIX, con la Revolución industrial y el acelerado proceso de urbanización y crecimiento de las urbes, la infancia sufrió pobreza y violencia, habiendo sido sometidas a trabajos forzados en las fábricas (Rodríguez y Mannarelli, 2007), en el Perú, en el mismo periodo, en pleno apogeo del pacto social de la modernidad, la infancia indígena, afrodescendiente y mestiza también fue sometida a trabajos forzados, no solo en las plantaciones agrícolas en las haciendas y latifundios de la costa y los Andes, sino también en los socavones mineros y en las fábricas durante el incipiente proceso de industrialización. Esta es nuestra matriz histórica como sociedad, que hunde sus raíces en la sociedad moderna/posmoderna, actualmente polarizada y fracturada, porque fue establecida y construida sobre la desigualdad, pobreza y marginación (Touraine, 2010).

Está claro entonces que el pacto social de la modernidad/posmodernidad ${ }^{26}$ significó y todavía significa para los sectores más pobres y segregados de nuestra sociedad su exclusión de los Derechos del Hombre y del Ciudadano. ${ }^{27}$ El reconocimiento de estos derechos solo ha sido posible para los occidentales y los blancos, y para aquellos que estuvieron presentes en el pacto social de

26 "Las promesas de la modernidad aún no están cumplidas. Pero ¿por qué no están cumplidas? Porque la única forma de que puedan ser cumplidas es con la desacralización total de la clasificación social de las gentes. El racismo está, sin duda, en crisis, porque hay conflictos y protesta mundial contra él, al mismo tiempo en que se inflan los 'fundamentalismos' racistas en muchos países. Porque la idea de igualdad social pasó a ser el sentido común de los mortales universalmente, pero la idea de raza ha sido practicada tan consistentemente durante más de quinientos años, que todo el mundo, yo diría el 99\% de la población de la especie, ha terminado siendo educada en esta misma perspectiva. [...] No se puede, en consecuencia, llevar a la práctica las promesas de la modernidad sin la destrucción de la colonialidad, es decir sin la descolonialidad del poder. Sin ella no se puede desacralizar la autoridad y otra forma de autoridad colectiva que no sea un Estado fundado en la desigualdad social racial, la más radical de todas. La modernidad aún opera, como se ve, colonialmente. Y la colonialidad, de su lado, también opera modernamente. Es decir, se co-bloquean, se co-limitan, se co-imponen, están co-activas, co-presentes todo el tiempo, en cada acto de cada uno de nosotros, en cada ámbito de la práctica social, en cada dimensión de las relaciones sociales" (Quijano, 2013, pp. 25-26).

27 " [...] los derechos del hombre y del ciudadano, que habían sido pensados en un mundo donde la 'matriz invisible' era blanca, compuesta de ciudadanos blancos fundamentalmente y no de indios y negros. En este esquema, las diferencias de género y de sexualidad fueron subsumidas por las clasificaciones raciales. No era ni es lo mismo ser mujer blanca que negra o de color. La colonialidad es constitutiva de la modernidad. Las relaciones asimétricas de poder, al mismo tiempo que la participación activa desde la diferencia colonial en la expansión del circuito comercial del Atlántico constituido a través de los siglos como Occidente o civilización occidental, son los que justifican y hacen necesario la 'colonialidad del poder' (Quijano, 1997) y de 'diferencia colonial' (Mignolo, 2000) para corregir las limitaciones histórico-geográficas a la vez que lógicas del concepto de geo-cultura” (Mignolo, 2005, p. 75). 
la modernidad, pero les fue negada a los no occidentales, a los indígenas, negros, mestizos, mujeres, niños y niñas, que habían sido pensados en un mundo donde la "matriz invisible" era blanca e integrada por ciudadanos blancos. Los niños indios, negros, mestizos y cholos fueron subsumidos por estas clasificaciones sociales de carácter racial y segregacionista. Esta racionalidad occidental eurocéntrica considera que todo lo que no es europeo es percibido como pasado, decadente, anacrónico e inferior.

El pacto social de la modernidad/posmodernidad sigue vigente, sin embargo, se encuentra sumida en una profunda crisis, y sus promesas de libertad, igualdad y fraternidad aún no se han cumplido cabalmente. Por ello, hoy día en el Perú la infancia en pobreza y pobreza extrema vive en permanente riesgo social, sintiéndose amenazada por las carencias crónicas a las que se les expone, en un Estado y sociedad donde los vínculos sociales y afectivos cada día son más precarios, y cuyo rasgo característico es el agravamiento de las desigualdades y exclusiones que afecta la vida y existencia social de la infancia. Revertir esta situación supone democratizar el Estado y la sociedad para terminar con el racismo en las relaciones sociales, y de este modo construir un país diferente al actual, recogiendo todas aquellas experiencias que anuncian el futuro, porque — como decía José Martí- los niños han nacido para ser felices. 


\section{Bibliografía}

Asociacion Bartolome Aripaylla (2014). Allin Kawsay en la visión de los Quispillactas. En Sumak Kawsay (vivir Bonito). Lima: Plataforma de Copartes terre des hommes-Alemania.

Baudrillard, J. (2012). Cultura y simulacro. Barcelona: Editorial Kairós.

Baudrillard, J. (2007). La sociedad de consumo. Sus mitos, sus estructuras. Madrid: Siglo XXI Editores.

Bauman, Z. (2011). Daños colaterales. Desigualdades sociales en la era global. Buenos Aires: Fondo de Cultura Económica.

Bauman, Z. (2005). La modernidad líquida. Buenos Aires: Fondo de Cultura Económica.

Bauman, Z. (1999). La globalización consecuencias humanas. Buenos Aires: Fondo de Cultura Económica.

Beck, U. (2002). La sociedad del riesgo: hacia una nueva modernidad. Barcelona: Paidós.

Boff, L. (2006). Virtudes para otro mundo posible. Hospitalidad: derecho y deber de todos (tomo I). Bilbao: Sal Terrae.

Boff, L. (2002a). Tiempo de trascendencia, El ser humano como un proyecto infinito. Bilbao: Sal Terrae.

Boff, L. (2002b). Fundamentalismo. La globalización y el futuro de la humanidad. Bilbao: Sal Terrae.

Boff, L. (2000). La dignidad de la tierra. Ecología, mundialización, espiritualidad: la emergencia de un nuevo paradigma. Valladolid: Editorial Trotta.

Bourdieu, P. (2005). Capital cultural. Escuela y espacio social. Buenos Aires: Siglo XXI Editores.

Bourdieu, P. (2002). Pensamiento y acción. Buenos Aires: Libros del Zorzal.

Bourdieu, P. (2000). La distinción. Criterios y bases sociales del gusto. Madrid: Taurus.

Castells, M. (2013). Comunicación y poder. México D. F.: Siglo XXI Editores.

Castillo, M. (2015). Ley, “metafísica” criolla y ciudadanía peruana. En M. Ledesma (Coord.). Justicia, derecho y sociedad, Debates interdisciplinarios para el Análisis de la justicia en el Perú. Lima: Centro de Estudios Constitucionales Tribunal Constitucional del Perú.

Castoriadis, C. (2006). Una sociedad a la deriva. Entrevistas y debates (1974-1977). Buenos Aires: Katz.

Cussianovich, A. (2011). Hacia un nuevo contrato social para la dignidad de los niños y niñas. Lima: INFANT. 
Cussianovich, A. (2009). Infancia y trabajo: dos nudos culturales en transformación. En Faro Número 1. Revista de la Unidad de Postgrado de la Universidad Politécnica Salesiana. Quito: Universidad Politécnica Salesiana.

Cussianovich, A. (2003). Historia del pensamiento social sobre infancia. Lima: Fondo Editorial de la Facultad de Ciencias Sociales de la Universidad Nacional Mayor de San Marcos.

De Sousa, B. (2010a). Refundación del Estado en América Latina. Perspectivas desde una epistemología del sur. Lima: Instituto Internacional de Derecho y Sociedad, Programa Democracia y Transformación Global.

De Sousa, B. (2010b). La hora de los invisibles. En I. León (Comp.). Sumak Kawsay/ Buen vivir y cambios civilizatorios. Quito: Editorial FEDAEPS.

De Sousa, B. (2006a). Renovar la teoría crítica y reinventar la emancipación social (encuentros en Buenos Aires). Buenos Aires: CLACSO.

De Sousa, B. (2006b). Conocer desde el sur. Para una cultura politica emancipatoria. Lima: Fondo Editorial de la Facultad de Ciencias Sociales de la Universidad Nacional Mayor de San Marcos.

Escobar, A. (2010). Una minga para el postdesarrollo. Lugar, medio ambiente y movimientos sociales en las transformaciones globales. Lima: Fondo Editorial de la Facultad de Ciencias Sociales de la Universidad Nacional Mayor de San Marcos.

Flores Galindo, A. (1999). La tradición autoritaria. Violencia y democracia en el Perú. Lima: APRODEH, Sur. Casa de Estudios del Socialismo.

Flores Galindo, A. (1988). Tiempo de plagas. Lima: Caballo Rojo Ediciones.

Freire, P. (2001). Pedagogía de la indignación. Madrid: Morata.

Galeano, E. (2002). Patas arriba. La escuela del mundo al revés. Madrid: Siglo XXI Editores.

Germaná, C. (2002). La racionalidad en las ciencias sociales. Lima: Fondo Editorial de la Facultad de Ciencias Sociales de la Universidad Nacional Mayor de San Marcos.

Giddens, A. (2008). Un mundo desbocado. Los efectos de la globalización en nuestras vidas. México D. F.: Taurus.

Guibal, F. y Ibáñez, E. (2009). Cornelius Castoriadis. Lo imaginario y la creación de la autonomía. Lima: Fondo Editorial de la Universidad Antonio Ruiz de Montoya.

Gramsci, A. (2004). Los intelectuales y la organización de la cultura. Buenos Aires: Ediciones Nueva Visión.

Huntington, S. (2013). El choque de civilizaciones y la reconfiguración del orden mundial. Barcelona: Paidós.

Jaramillo, E. (2009). ¿Dónde dormirán los niños pobres del Perú? A propósito de la Ley que protege a los menores de edad de la mendicidad. En Faro Número 1. Revista de 
la Unidad de Postgrado de la Universidad Politécnica Salesiana. Quito: Universidad Politécnica Salesiana.

Jaramillo, E. (2004). Culturas y políticas sociales de infancia y protagonismo en los escenarios futuros. Arequipa: Separata.

Joseph, J. (2005). La ciudad, la crisis y las salidas. Democracia y desarrollo en espacios urbanos meso. Lima: Alternativa, Fondo Editorial de la Facultad de Ciencias Sociales de la Universidad Nacional Mayor de San Marcos.

Klarén, P. (2004). Nación y sociedad en la historia del Perú. Lima: IEP.

León, R. (2008). El Perú de nuestros días. Una perspectiva psicológica. En El Perú y el mundo actual. Retos del presente. Lima: Editorial Universitaria, Universidad Ricardo Palma.

Mac Gregor, F. (2002). Reflexión sobre el Perú. Lima: Fondo Editorial de la Pontificia Universidad Católica del Perú.

Mac Lean y Estenos, R. (1948). Los negros en el Nuevo Mundo. Lima: Editorial PTCM.

Maffesoli, M. (2004). El tiempo de las tribus: el ocaso del individualismo en las sociedades posmodernas. México D. F.: Siglo XXI Editores.

Mannarelli, M. E. (2002). La infancia y la configuración de los vínculos en el Perú: un enfoque histórico. En politicas públicas e infancia en el Perú. Recomendaciones. Lima: Niños del Milenio-Save the Children UK.

Mariátegui, J. C. (1980). 7 ensayos de interpretación de la realidad peruana. Lima: Biblioteca Amauta.

Mejía Navarrete, J. (2015). Corrupción, violencia, cinismo. Notas sobre la insensibilidad moral del Perú. En M. Ledesma (Coord.). Justicia, derecho y sociedad. Debates interdisciplinarios en el Perú. Lima: Centro de Estudios Constitucionales, Tribunal Constitucional.

Mendivil, J. (2013). Perú hacia el Bicentenario Sociedad Intercultural. Lima: Editorial Universitaria, Universidad Ricardo Palma.

Mignolo, W. (2007). Hermenéutica de la democracia: el pensamiento de los límites y la diferencia colonial. En Democracia profunda: reinvenciones nacionales y subjetividades emergentes. Río de Janeiro: Academia de la Latinidad.

Mignolo, W. (2005). La colonialidad a lo largo y a lo ancho. En E. Lander (Coord.). La colonialidad del saber: eurocentrismo y ciencias sociales. Perspectivas latinoamericanas. Buenos Aires: CLACSO.

Nugent, G. (2010). El orden tutelar. Sobre las formas de autoridad en América Latina. Lima: CLACSO, DESCO.

Plaza, O. (1998). Desarrollo rural. Enfoque y métodos alternativos. Lima: Fondo Editorial de la Pontificia Universidad Católica del Perú. 
Portocarrero, G. (2015). La urgencia por decir “nosotros". Los intelectuales y la idea de nación en el Perú republicano. Lima. Fondo Editorial Pontificia de la Universidad Católica del Perú.

Portocarrero, R. (1995). El trabajo infantil en el Perú: apuntes de interpretación histórica. Lima: Radda Barnen-Ifejant.

Quijano, A. (2011). Bien vivir entre el "desarrollo" y la des/colonialidad del poder. Revista Especializada de Ciencias Sociales, 74. Quito.

Quijano, A. (2010). América Latina hacia un nuevo horizonte histórico. En I. León (Comp.). Sumak Kawsay/Buen vivir y cambios civilizatorios. Quito: Editorial FEDEAPS.

Quijano, A. (2009). La colonialidad del poder y subjetividad en América Latina. En C. Pimentel (Coord.). Poder, ciudadanía y salud mental en el Perú. Lima: CECOSAM. Quijano, A. (2014). “Bien vivir”: entre el “desarrollo” y la des/colonialidad del poder. En A. Quijano (Ed.). Des/colonialidad y bien vivir. Un nuevo debate en América Latina. Lima: Cátedra América Latina y la Colonialidad del Poder, Editorial Universitaria, Universidad Ricardo Palma.

Quijano, A. (2008). El trabajo al final del siglo XX. Revista Especializada de Ciencias Sociales, 74(XX). Quito.

Quijano, A. (2007). Don Quijote y los molinos de viento de América Latina. En J. I. López Soria (Comp.). Andinos y mediterráneos. Claves para pensar Iberoamérica. Lima: Fondo Editorial del Congreso del Perú, Organización de Estados Iberoamericanos para la Educación, la Ciencia y la Cultura.

Quijano, A. (2005). Colonialidad del poder, eurocentrismo y América Latina. En E. Lander (Comp.). La colonialidad del saber: eurocentrismo y ciencias sociales. Perspectivas latinoamericanas. Buenos Aires: CLACSO.

Quijano, A. (1998). La economía popular y sus caminos en América Latina. Lima: Mosca Azul Editores.

Rodríguez, P. (2007). Los hijos del sol. Un acercamiento a la infancia en la América prehispánica. Historia de la infancia en América Latina. En P. Rodríguez y M. E. Mannarelli. Bogotá: Universidad Externado de Colombia.

Rodríguez, P. Mannarelli, M. E. (2007). Introducción. En P. Rodríguez y M. E. Mannarelli. Historia de la infancia en América Latina. Bogotá: Universidad Externado de Colombia.

Rostworowski, M. (2009). Historia del Tahuantinsuyo. Lima: IEP.

Sánchez-Parga, J. (2004). Orfandades infantiles y adolescentes, introducción a una sociología de la infancia. Quito: Universidad Politécnica Salesiana, Maestría en 
Política Social para la Promoción de la Infancia y Adolescencia, ABYA YALA, Save the Children Suecia, Red Latinoamericana de Maestría en Derechos de Infancia.

Silva Santisteban, F. (2004). Prólogo. En G. Alcántara. El Perú frente a la globalización: necesidad de una revolución mental. Lima: Editorial San Marcos.

Subirats, D. (2005). Viaje al fin del paraíso. Barcelona: Losada.

Touraine, A. (2010). ¿Cómo salir del liberalismo? Barcelona: Paidós.

Trisciuzzi, L. y Cambi, F. (2003). Infancia e historia. Lima: IFEJANT.

Ugarteche, O. y Martínez-Ávila, E. (2013). La gran mutación. El capitalismo real del siglo XXI. Lima: Lápix Editores.

Weber, M. (2010). Conceptos sociológicos fundamentales. Madrid: Alianza Editorial.

Wallerstein, I. (2006). Abrir las ciencias sociales. México D. F.: Siglo XXI Editores.

Wallerstein, I. (2004). Las incertidumbres del saber. Barcelona: Gedisa.

Wallerstein, I. (2003). El capitalismo histórico. México D. F.: Siglo XXI Editores. 